\title{
Cryptosporidiosis - an occupational risk and a disregarded disease in Estonia
}

Brian Lassen ${ }^{1 *}$, Marie Ståhl ${ }^{2}$ and Heidi L Enemark ${ }^{2}$

\begin{abstract}
Background: Cases of cryptosporidiosis have not been officially reported in Estonia after the year 2000, and the disease appears to be either under-diagnosed or under-reported.

Findings: Based on a human case of cryptosporidiosis contracted during faecal sampling in dairy farms, cattle considered to be sources of infection were analysed for Cryptosporidium spp. by a modified Ziehl Neelsen technique and molecular typing. C. parvum subtype llaA16G1R1 was detected from the human case and from calves from one of nine farms enrolled in the study providing strong circumstantial evidence of zoonotic transmission from calves to humans.
\end{abstract}

Conclusion: Cryptosporidiosis presents an occupational risk to people with cattle contact, and may also be a risk to the human population in general. Thus increased public and medical awareness is warranted.

Keywords: Cryptosporidium parvum, Estonia, Genotype, Human, Zoonoses, Cattle

\section{Findings}

Cryptosporidiosis is a diarrhoeal disease caused by the multiplication of protozoan parasites in the small intestine. In humans, cryptosporidiosis is most commonly caused by either $C$. hominis, which is predominantly host specific, or the zoonotic $C$. parvum which is highly prevalent in young calves and much less host specific [1]. In 2007, environmentally robust $C$. spp. oocysts were found in $84 \%$ of Estonian dairy cattle herds [2]. Despite the fact that the parasite is shed by $24 \%$ of calves $<3$ months of age it is rarely diagnosed or treated [2,3].

The European Centre for Disease Prevention and Control (ECDC) has stated that food-and waterborne pathogens causing diarrhoea, such as $C$. spp., are of increasing importance [4]. Further it is stressed that improvement of this situation is impaired by underdiagnosing and under-reporting. In Estonia, no new cases of cryptosporidiosis have been reported by the National Health Board after year 2000 [5], although cases have been present as described here. This lack of reported cases of cryptosporidiosis is surprising considering the numerous Estonian cases of giardiasis [4],

\footnotetext{
*Correspondence: brian.lassen@gmail.com

'Institute of Veterinary Medicine and Animal Sciences, Estonian University of Life Sciences, Kreutzwaldi 62, 51014 Tartu, Estonia

Full list of author information is available at the end of the article
}

caused by a protozoan parasite with transmission routes similar to Cryptosporidium.

To increase awareness of this issue we present a case of cryptosporidiosis in a 32 year old man with no history of chronic diseases or previous Cryptosporidium infection. The man visited nine randomly selected dairy farms in the Estonian counties Harjumaa, Läänemaa, and Saaremaa during a period of three days in January 2007. As part of a university research team, he singlehandedly collected faecal samples from 49 young calves in the farms, and was the only member of the research team who became clinically infected with Cryptosporidium. During the period from ten days prior to the last farm visit until the symptom debut, he reported no animal contact besides contact with the study farm, nor did he work with any other faecal samples. The symptoms included stomach cramps, nausea, loss of appetite, fatigue, muscle aches, fever, and malodorous, watery diarrhoea. The clinical symptoms first appeared four days after the last farm visit, and continued with varying intensity for a total of 19 days. Faecal samples taken on days 6 and 14 after the last farm visit, during the most severe diarrhoeal period, were studied using a semi-quantitative, modified Ziehl-Neelsen staining technique [6]. On day 6 and 14, respectively, 1-5 and >25 Cryptosporidium oocysts were observed per field of vision at a magnification of 400 . 
Using a commercial kit (E.Z.N.A. ${ }^{\bullet}$ Stool DNA Kit, Omega Bio-Tek Inc.), DNA was extracted from both of these human samples $(\mathrm{n}=2)$, and from Cryptosporidium positive bovine samples from calves aged $<3$ months $(\mathrm{n}=3)$, $3-12$ months $(n=3)$, and $>12$ months $n=3)$ representing nine different farms that could have acted as a potential source of the human infection. Samples for genotyping were selected on the basis of Cryptosporidium oocysts being present in numbers above 100,000 per gram faeces. The DNA was subsequently submitted to the National Veterinary Institute in Denmark for molecular analysis.

Identification of Cryptosporidium to the species level was done by polymerase chain reaction (PCR) amplification and sequencing of the small subunit ribosomal RNA gene (18S rDNA locus) and the $70-\mathrm{kDa}$ heat shock protein gene (HSP70) as previously described [7,8], and subtyping was performed using a nested PCR to amplify a $~ 550$ bp fragment of the hyper variable glycoprotein (gp) 60 gene [9]. Subtypes were named according to nomenclature described by Sulaiman et al. [10]. Cryptosporidium isolated from the human case as well as from one calf from Raplamaa were identified as C. parvum, and 99-100\% identical GenBank sequences at the $18 \mathrm{~S}$ rDNA locus and HSP70 gene respectively (e.g. AF093493.1; AB542125). Subtyping revealed subtype IIaA16G1R1 [GenBank: KJ769462, KJ769463].

This subtype has mainly been described in calves from Eastern Europe [11-15] but cases in other production animals such as lambs [16] and pigs [17] have also been reported from this part of Europe, and human cases have been described in Slovenia [14] suggesting that this strain may serve as reservoir for human infections.

A physician was consulted and presented with the evidence of clinical cryptosporidiosis 19 days after the initial calf-contact. It then became clear that normal procedure in such gastroenteric cases is symptomatic treatment without any attempts of making a specific diagnosis. In September 2008, the case was reported to health professionals as a work related infection in an occupational health check.

One third of examined Estonian cattle has been shown to excrete Cryptosporidium oocysts, and both C. parvum and $C$. andersoni have been identified in the population [18]. In 2009, an Estonian study showed that the highest proportion of calves shedding oocysts was seen in animals above 12 months of age, while the highest intensity of infection was observed in calves younger than 3 months [2]. Cryptosporidium isolates from this study were not genotyped, however, other studies have shown a strong correlation between age and species/ genotype e.g. $[19,20]$, which is highly relevant as regards risk of zoonotic infection since young calves primarily shed the zoonotic $C$. parvum whereas older cattle excrete more host specific species. It is thus expected that transmission of Cryptosporidium may occur from young calves to humans, particularly those occupied in the livestock industry, and the present case is in agreement with similar observations in other countries [1,21,22]. Although not officially reported, several veterinary students attending farm visits arranged by the Estonian University of Life Sciences have experienced clinical symptoms consistent with cryptosporidiosis after visiting cattle farms in Estonia.

Cryptosporidiosis is particularly dangerous for young and immunosuppressed individuals. Zoonotic transmission as well as contact with family members suffering from cryptosporidiosis present risks to human immunodeficiency virus (HIV) patients for contracting the disease [23,24]. In Estonia HIV/AIDS is considered epidemic, peaking in 2001 [25]. In 2008, the cases per 100,000 inhabitants reached 40.6 and 4.6 for HIV and AIDS cases respectively [25]. In conclusion, the present situation in Estonia calls for increased awareness towards cryptosporidiosis as a general and an occupational health problem.

\section{Competing interests}

The authors declare no conflict of interests.

\section{Authors' contributions}

$\mathrm{BL}$ presented the idea of the study, collected samples, analysed samples, and drafted the manuscript. MS and HLE carried out molecular analysis and participated in the writing of the manuscript. All authors accepted the final version of the manuscript. All authors read and approve the final manuscript.

\section{Acknowledgements}

Pikka Jokelainen for language editing and Boi-Tien Thi Pham for skilled laboratory assistance. Jevgenia Epštein for valuable input on the Estonian recording system. Funding was provided by the Estonian Research Council, health promotion research programme TerVe 3.2.1002.11-0002 EKZE_SS.

\section{Author details}

${ }^{1}$ Institute of Veterinary Medicine and Animal Sciences, Estonian University of Life Sciences, Kreutzwaldi 62, 51014 Tartu, Estonia. ${ }^{2}$ Technical University of Denmark, DK-1870 Frederiksberg C, Denmark.

Received: 21 January 2014 Accepted: 20 May 2014

Published: 5 June 2014

\section{References}

1. Chako CZ, Tyler JW, Schultz LG, Chiguma L, Beerntsen BT: Cryptosporidiosis in people: it's not just about the cows. J Vet Intern Med 2010, 24:37-43.

2. Lassen B, Viltrop A, Raaperi K, Järvis T: Eimeria and Cryptosporidium in Estonian dairy farms in regard to age, species, and diarrhoea. Vet Parasitol 2009, 166:212-219.

3. Estonian. Veterinary Diagnostic and Food Laboratories (VAFL): Aastaaruaned. 2012, [http://www.vetlab.ee]

4. European Centre for Disease Prevention and Control (ECDC): Annual Epidemiological Report 2011. Reporting on 2009 Surveillance Data and 2010 Epidemic Intelligence Data. Stockholm: ECDC; 2011:77-79.

5. Estonian Health Board: Nakkushaigused Eestis. [http://www.terviseamet.ee/ nakkushaigused/nakkushaigustesse-haigestumine.html]

6. Henriksen SA, Pohlenz JF: Staining of cryptosporidia by a modified Ziehl-Neelsen technique. Acta Vet Scand 1981, 22:594-596.

7. Enemark HL, Ahrens P, Juel CD, Petersen E, Petersen RF, Andersen JS, Lind P, Thamsborg SM: Molecular characterization of Danish Cryptosporidium parvum isolates. Parasitology 2002, 125:331-341.

8. Morgan UM, Monis PT, Xiao L, Limor J, Sulaiman I, Raidal S, O'Donoghue P, Gasser R, Murray A, Fayer R, Blaqburn BL, Lal AA, Thompson RC: Molecular 
and phylogenetic characterisation of Cryptosporidium from birds. Int Parasitol 2001, 31:289-296.

9. Peng MM, Wilson ML, Holland RE, Meshnick SR, Lal AA, Xiao L: Genetic diversity of Cryptosporidium spp. in cattle in Michigan: implications for understanding the transmission dynamics. Parasitol Res 2003, 90:175-180

10. Sulaiman IM, Hira PR, Zhou L, Al-Ali FM, Al-Shelahi FA, Shweiki HM, Iabal J, Khalid N, Xiao L: Unique endemicity of cryptosporidiosis in children in Kuwait. J Clin Microbiol 2005, 43:2805-2809.

11. Imre K, Lobo LM, Matos O, Popescu C, Genchi C, Dărăbuş G: Molecular characterisation of Cryptosporidium isolates from pre-weaned calves in Romania: is there an actual risk of zoonotic infections? Vet Parasitol 2011, 181:321-324.

12. Kváč M, Hromadová N, Květoňová D, Rost M, Sak B: Molecular characterization of Cryptosporidium spp. in pre-weaned dairy calves in the Czech Republich: absence of $C$. ryanae and management-associated distriburion of $C$. andersoni, C. bovis and C. parvum subtypes. Vet Parasitol 2011, 177:378-382.

13. Ondrácková Z, Kvác M, Sak B, Kvetonová D, Rost M: Prevalence and molecular characterization of Cryptosporidium spp. in dairy cattle in South Bohemia, the Czech Republic. Vet Parasitol 2009, 165:141-144.

14. Soba B, Logar J: Genetic classification of Cryptosporidium isolates from humans and calves in Slovenia. Parasitology 2008, 135:1263-1270.

15. Plutzer J, Karanis P: Genotype and subtype analyses of Cryptosporidium isolates from cattle in Hungary. Vet Parasitol 2007, 146:357-362.

16. Imre K, Luca C, Costache M, Sala C, Morar A, Morariu S, llie MS, Imre M, Dărăbuş G: Zoonotic Cryptosporidium parvum in Romanian newborn lambs (Ovis aries). Vet Parasitol 2013, 191:119-122.

17. Kvác M, Sak B, Hanzlíková D, Kotilová J, Kvetonová D: Molecular characterization of Cryptosporidium isolates from pigs at slaughterhouses in South Bohemia, Czech Republic. Parasitol Res 2009, 104:425-428.

18. Lassen B: Diagnosis, Epidemiology and Control of Bovine Coccidioses in Estonia. PhD Thesis. Tartu: Ecoprint; 2009.

19. Dixon B, Parrington L, Cook A, Pintar K, Pollari F, Kelton D, Farber J: The potential for zoonotic transmission of Giardia duodenalis and Cryptosporidium spp. from beef and dairy cattle in Ontario, Canada. Vet Parasitol 2011, 175:20-26.

20. Langkjaer RB, Vigre H, Enemark HL, Maddox-Hyttel C: Molecular and phylogenetic characterization of Cryptosporidium and Giardia from pigs and cattle in Denmark. Parasitology 2007, 134:339-350.

21. Gait R, Soutar RH, Hanson M, Fraser C, Chalmers R: Outbreak of cryptosporidiosis among veterinary students. Vet Rec 2008, 162:843-845.

22. Autio T, Karhukorpi J, Mäkelä M, Meri T, Savolainen S, Rimhanen-Finne R: Endemic cryptosporidiosis-underdiagnosed disease in Finland. Duodecim 2012, 28:1887-1890

23. Gatei W, Suputtamongkol Y, Waywa D, Ashford RW, Bailey JW, Greensill J, Beeching NJ, Hart CA: Zoonotic species of Cryptosporidium are as prevalent as the anthroponotic in HIV-infected patients in Thailand. Ann Trop Med Parasitol 2002, 96:797-802.

24. Izadi M, Jonaidi-Jafari N, Saburi A, Eyni H, Rezaiemanesh MR, Ranjbar R: Prevalence, molecular characteristics and risk factors for cryptosporidiosis among Iranian immunocompromised patients. Microbiol Immunol 2012, $56: 836-842$.

25. Laisaar KT, Avi R, DeHovitz J, Uusküla A: Estonia at the threshold of the fourth decade of the AIDS era in Europe. AIDS Res Hum Retroviruses 2011 27:841-851.

doi:10.1186/1751-0147-56-36

Cite this article as: Lassen et al:: Cryptosporidiosis - an occupational risk and a disregarded disease in Estonia. Acta Veterinaria Scandinavica 2014 56:36.

\section{Submit your next manuscript to BioMed Central and take full advantage of:}

- Convenient online submission

- Thorough peer review

- No space constraints or color figure charges

- Immediate publication on acceptance

- Inclusion in PubMed, CAS, Scopus and Google Scholar

- Research which is freely available for redistribution

Submit your manuscript at www.biomedcentral.com/submit
C Biomed Central 